\title{
A Design of Online Teacher Training Based on Learning Management System (LMS) to Improve Quality of Teaching on Higher Order Thinking Skill (HOTS)
}

\author{
Caraka Putra Bhakti $^{1}$, Siti Urbayatun ${ }^{2}$, Suyatno $^{3}$, Ika Maryani ${ }^{4}$, Dwi Sulisworo ${ }^{5}$, \\ Muhammad Alfarizqi Nizamuddin Ghiffari ${ }^{6}$, Panji Nur Fitri Yanto ${ }^{7}$ \\ ${ }^{1,6,7}$ Guidance and Counseling, Ahmad Dahlan University Yogyakarta, Indonesia, Psychology, ${ }^{3} \mathrm{Ahmad}$ \\ Dahlan University Yogyakarta, Indonesia ${ }^{2}$, Education Management, Ahmad Dahlan University \\ Yogyakarta, Indonesia, ${ }^{4}$ Elementary Education, Ahmad Dahlan University Yogyakarta, Indonesia \\ ${ }^{5}$ Physical Education Ahmad Dahlan University Yogyakarta, Indonesia \\ "caraka.pb@bk.uad.ac.id
}

\begin{abstract}
This study aims to design online training for teachers based on a learning management system (LMS) so that teachers can provide higher-order thinking skills (HOTS) learning. In the era of the industrial revolution 4.0, the need for competent human resources is shown from the capabilities they have. Higher-order thinking skills are abilities that a person needs to have since sitting in school. This ability needs to be developed through learning in schools. The teacher's role determines to learn in the class that can increase students' HOTS. Thus, it is necessary to conduct training for teachers to be competent in providing learning that emphasizes HOTS. The internet can be one of the tools that can be used in developing HOTS, so that teacher training can be done online without being limited to any situation. The design of the training provided is focused on the way the teacher manages the class, an understanding of the characteristics of students, the ability of the teacher to prepare material, and several other training items.
\end{abstract}

Keywords: Higher Order Thinking Skill; Teacher Training; LMS

\section{Introduction}

Indonesia is entering the era of the industrial revolution 4.0, where competition and development are a necessity for all sectors, one of which is education. The era of the industrial revolution 4.0 became an era where humans were always in touch with technology and information [1]. Even so, the 4.0 industrial revolution made it easy for humans [2]. Education today needs to adjust to the industrial revolution of 4.0, which demands a variety of abilities. If the human ability does not develop, then the role of humans can be shifted. Even though in the era of the industrial revolution, 4.0 people were facilitated, human resources could be replaced by existing technology [1]. One of the abilities that need to be possessed today is higher-order thinking skills.

Higher-order thinking skills (HOTS) is a process of thinking not only in understanding someone learning something but also being able to take advantage, apply it in their 
environment, and create innovation. It can be said that higher-order thinking skills are one's ability to think so that they can acquire new knowledge [3], [4]. Also, HOTS in bloom taxonomy is very closely related to several abilities such as critical thinking, creativity, and so on [5]. Thus, increasing HOTS in students will significantly help students to become individuals who can survive in the current era.

Through structured and well-structured education, HOTS can be owned by students and can be developed optimally. Higher-order thinking skills can be one of the potential needs of students in developing knowledge and technology in the current era [4], [6]. Teachers have an essential role in the administration of education. In curriculum 2013, it's important to teach student about HOTS by design the learning more focus on problem solving task [7]. Thus, for HOTS that students have to develop optimally, teachers need to have sufficient capacity and ability to master the concepts of HOTS themselves.

Teachers need to train and continue to learn the concepts of HOTS by doing various kinds of training. As a profession, students and the teaching profession are closely related to developing potential; this is because the teacher is optimizing the development potential [8]. In the other hand, as a profession, teacher is not just a work but a unique thing that has the characteristics of expertise [9]. The training, which is followed by the teacher, will be able to develop competencies and make teachers able to provide learning that instills HOTS to students. The training is given to the teacher given by an expert who has the experience and understands HOTS's concepts. It should be understood that the quality of education is limited to certification and the abilities, strategies of teachers, and other abilities [8].

However, currently, teacher training is experiencing limitations. This limitation indicated by a variety of phenomena such as the coronavirus pandemic (Covid-19), which has been ongoing for six months in Indonesia. Thus, the concept of HOTS training for teachers needs to be updated and adjusted to current conditions, so that the training given to teachers can continue and be provided.

The development of technology such as the internet makes it easy for many people, especially educators, to provide classes to students. Online-based learning becomes learning that is considered severe in the current era because this learning can facilitate broader, varied, and exciting learning [10]. The concept of online learning can be utilized in providing training to teachers. Thus, teachers will continue to receive training without limited conditions that are not conducive.

\section{a. Higher Order Thinking Skill (HOTS)}

The current environment requires a variety of abilities such as critical thinking, creativity, collaboration, and so forth. However, it can be trained with higher-order thinking skills (HOTS) developed by teachers to students. HOTS will significantly assist students in learning-related concepts from science better [11]. Thus, HOTS can be developed so that someone has the skills needed in the current era.

HOTS can be defined as cognitive abilities at the C4 level in analysis, C5 in Synthesis, and C6 in Evaluation [4], [12]. HOTS is the level in the human mindset in which its implementation is carried out to evaluate a matter. Besides, with HOTS, students will have the potential to develop technology and knowledge, which is done more attractively and able to solve human-environmental problems [4], [6]. Thus, if this level can be applied in learning, it can be said that the learning use is implemented based on HOTS.

\section{b. Teacher Competency Development}

In optimizing the ability of teachers to teach, competence becomes one of the indicators of teacher development. This development is because the teacher's more professional learning will 
have a high impact on teaching and learning [13]. The importance for teachers to continue to develop their competencies. Various ways can be done in developing teacher competencies.

Lesson study is one way to develop teacher competencies. Lesson study is a teacher's professional development program that was created in Japan [14]. This lesson study is done by collaborating with other teachers, supervising with experts, and discussing each other over the same problem. In lesson study, each teacher will discuss and collaborate on solving a problem, and the activity will help teachers find new ways of learning [8]. Thus the lesson study will obtain excellent abilities through experience that has been received before and the results of fellow teacher discussions.

Also, there is an online learning community (OLC). Here teacher competencies will be developed with a variety of activities carried out online. Here teachers will be brought together with experts online, which will help develop their competence [8]. The activities carried out such as online discussions with fellow teachers, experts to other networks. Each member of the OLC will share information and discuss issues related to difficulties experienced in developing teacher competence [15]. The output of this competency development model is more flexible in developing teacher competencies, even though face-to-face meetings are going forward.

Another model that can be applied to developing teacher competency is the scaffolding model. This model uses three main aspects: diagnosis, responsiveness, and handover [8], [16]. Activities in developing this scaffolding model are diagnoses to look for strengths and weaknesses, responsiveness to establish communication and thought development, handover is more to provide space for teachers to develop. The output of this model is to obtain higher quality teacher competencies and understand teachers more comprehensively.

Although there are various types of teacher competency development currently available, it is essential to note that each school and teacher has their method that suits their characteristics. Not all the development of teacher competency can be applied. Thus, in developing teacher competency, it is necessary to look at the teacher's situation, characteristics, conditions, and needs.

\section{c. Learning Management System (LMS)}

Learning today needs to use a better and current system following the times. Not leaving the old way, the new way of teaching gives flexibility and ability to optimize learning in the old way. By using media and technology, learning can be carried out quickly, one of them is by learning management systems or LMS.

LMS is a system that can be applied in providing structured learning. LMS is a software application that is used. There are structured hosts and learning materials for students online at any time [17]. The virtue of a Learning Management System (LMS) can be determined based on the LMS needs from two different perspectives. Namely: developers and users, so that evaluations can be carried out by users and the needs of two perspectives are conceptually formed from the literature studies conducted [18]. Thus, LMS provides convenience in the learning process.

Some various websites or platforms provide LMS tools for teaching. Moodle $₫$ is a platform that can be used online with easy access and relatively complete features. In Moodle ${ }^{\circledR}$, the teacher can provide learning material, assignments, and have discussions online. 


\section{Research Method}

This research uses the RnD method, which is carried out through several stages. Research and development methods are used to make various kinds of products, and tests are carried out to determine its effectiveness [19]. The stages carried out in this study began with gathering research sources such as finding a literature review, then conducting an analysis, then making a design, and conducting training. In this study, it was carried out only at the design stage.

This research's primary focus is to produce designs from LMS-based online training, which can be given to teachers to develop their competencies to provide learning that is in line with HOTS. This study and research source is based on journals, conferences, and experts who understand in the field of HOTS and teacher competency development.

\section{ReSUlt AND DisCuSSION}

\section{a. Teacher Training improves HOTS}

Providing training to teachers that are following HOTS is something that needs to be prepared carefully. To learn HOTS that will be given to students, teachers need to have high enough competence. Studying HOTS can also be interpreted as practicing and engaging oneself to behave with HOTS abilities.

In the training that develops HOTS, the first thing to consider is understanding the characteristics of teachers and schools. There are various models of training or development of teacher competencies. Teacher competencies can be developed with models, sustained and regular activities, Job Embedded, Collaboration, Coaching, and Using Technology [13]. In this study, the five models can be used and applied in the same program but at different times.

However, in providing teacher training, there are characteristics of training that must be present for the training to run well. According to DeMonte, there are five characteristics of professional teacher training, among others: definite goals and standards, focus on content, provide opportunities for active learning, have opportunities to collaborate, and there are feedback and follow-up [13]. Although schools and teachers' characteristics vary, essential points of teacher training need to be raised when developing teacher training.

After identifying the training model, the next step is to prepare the material to be given. In this case, the school needs' priority is determined in advance, so the material provided is appropriate. The core material is provided in training, such as understanding HOTS, forms of activities that use HOTS, and so on.

After the model and material have been prepared, the next step is to arrange the form of assignments, duration, and session duration. In this study, we planned training with a duration of 32 hours divided into four days, four days in 2 days each. The duration of the training was made to make it easier for teachers to take part in the training without overloading their schedules.

The form of assignments given to teachers who participated in the training. Following HOTS, the teacher collects learning outcomes from material that has been given with the HOTS model. Such for example, creating a material, analyzing a case, and so on. Experiences and learning to improve teacher competence are limited to the material received. Still, they are more interactive and many activities so that teachers understand HOTS is not only limited to theory but also experience. 
The 32-hour training schedule is as follows.

\begin{tabular}{lll} 
& \multicolumn{2}{l}{ Table 1. Material Design Training Activities } \\
\hline Session activity & Material Activities & Duration of activities \\
\hline First Session & Assessment of Teacher Needs & 2 hours \\
& Introduction to HOTS & 2 hours \\
& Open Discussion about HOTS & 2 hours \\
& Evaluation of sessions 1 & 2 hours \\
Second Session & Teaching strategy & 2 hours \\
& Teaching methods & 2 hours \\
& $\begin{array}{l}\text { Teaching Design Project } \\
\text { Evaluation of sessions 2 hours }\end{array}$ & 2 hours \\
& $\begin{array}{l}\text { HOTS-based learning design } \\
\text { Third Session }\end{array}$ & 2 hours \\
& $\begin{array}{l}\text { Preparation of HOTS-based } \\
\text { learning media }\end{array}$ & 2 hours \\
& $\begin{array}{l}\text { Open discussion HOTS-based } \\
\text { learning design }\end{array}$ & 2 hours \\
& $\begin{array}{l}\text { Evaluation of sessions } 3 \\
\text { Implementation of HOTS design } \\
\text { and media }\end{array}$ & 2 hours \\
& Supervision & 2 hours \\
& $\begin{array}{l}\text { Evaluation of HOTS learning } \\
\text { design }\end{array}$ & 2 hours \\
& $\begin{array}{l}\text { Training feedback and further } \\
\text { monitoring }\end{array}$ & 2 hours \\
\hline
\end{tabular}

After four days are finished, in the last session, trainees will be asked to provide training feedback and commit to carrying out learning according to HOTS. Of course, it does not stop with commitment but will always be monitored by the HOTS learning achievements. Thus, through this training offset the teacher to learn to improve their competence with theory and also experience.

\section{b. Design of LMS in developing HOTS in teacher}

Training Providing training to teachers directly requires a variety of preparations. Careful preparation also applies to online LMS-based teacher training. The LMS that is used in teacher training needs to pay attention to the form of tasks the teacher does in training, the process of assigning work and providing material to teachers, and the process of assigning tasks, feedback, and evaluation.

Some LMS that we know that can be used is moodle ${ }^{\circledR}$ or blackboard ${ }^{\circledR}[20]$. This online LMS-based training uses the Moodle $\mathbb{R}$ platform, which has various features that support teacher training. The features provided such as the provision of interactive material, collection of tasks that are comprehensive and easy to use. In this Moodle $\AA$, the training organizers will compile and design the form of activities in each session. 
The form of assignments given to teachers in this online LMS can be in the form of long term projects, group discussions, case studies, and so on. The assignment of these tasks is determined based on what is listed in HOTS. Thus, the task's form is adjusted to the skills learned and given to students. Through this form of assignment, the teacher will learn how to make assignments to students based on the experiences teachers feel.

The teaching material in this training is partly a teaching material related to pedagogical competence. Pedagogic competencies are teacher competencies which emphasize the ability of teachers to think and implement abilities in teaching. Pedagogic competencies that will be taught by teachers, such as material about class characteristics, student characteristics, public speaking skills, Creativity and Innovation, teaching strategies, and several other materials. Besides, the teacher will also be taught about HOTS's concepts, accompanied by concrete examples.

The collection of tasks in this training is essential. Assignments collected by the teacher through training will be an evaluation of the training in developing content and ways of providing training. The task collection is done through Moodle ${ }^{\circledR}$ by uploading files or documents. The uploaded file or document can be in the form of videos, summaries, drawings, or simple scripts that can be used as discussion material between teachers in training. The collected tasks will also determine to what extent the teacher's ability and teacher's competence in providing HOTS learning.

The collection of tasks and all forms of previous activities need to be evaluated to obtain feedback in improving training. Training evaluations and feedback are provided in digital

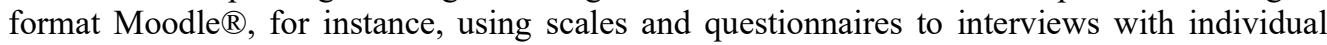
teachers. The evaluation in this training will examine the level of competence of teachers in teaching HOTS. Thus, there will be specific tasks for teachers who have less competence than other teachers - the following table of activities and activities during the training.

Table 2. Design of Training Activities and Training Tasks

\begin{tabular}{|c|c|c|}
\hline Activity Material & Activity Forms & Task Collecting Assignments \\
\hline Teacher Needs & Online Assessment & - \\
\hline Introduction to HOTS & Conference & Essay \\
\hline Open Discussion about HOTS & Community Chat & Accumulation discussion \\
\hline Teaching strategies & Interactive Video & Observation Essay \\
\hline Teaching methods & $\begin{array}{l}\text { Practical / } \\
\text { Experiential learning }\end{array}$ & Online Practice \\
\hline Project learning plans & Group Project & Online Submission \\
\hline HOTS based learning design & Group Project & Online Presentation \\
\hline $\begin{array}{l}\text { Preparation of HOTS based } \\
\text { learning media }\end{array}$ & Project based learning & Individual Report \\
\hline $\begin{array}{l}\text { Open discussion HOTS based } \\
\text { learning design }\end{array}$ & Community Chat & Accumulation discussion \\
\hline $\begin{array}{l}\text { Implementation HOTS Teaching } \\
\text { Plan and HOTS Media }\end{array}$ & Job Embedded & Student study report \\
\hline Supervision & Coaching & Individual Report \\
\hline $\begin{array}{l}\text { Evaluation of HOTS Learning } \\
\text { Design }\end{array}$ & Community Chat & Individual Report \\
\hline $\begin{array}{l}\text { Training Feedback and Further } \\
\text { Monitoring }\end{array}$ & Online Feedback & - \\
\hline $\begin{array}{l}\text { Evaluation of sessions } 1 \\
\text { Evaluation of sessions } 2 \\
\text { Evaluation of sessions } 3\end{array}$ & Online Discussion & Online Chat \\
\hline
\end{tabular}


All a teacher training plan and design described in the previous table may change at any time. Changes in the activity plan table adjust the needs of each school. This training design can be applied at school or home, without being hindered by conditions and situations.

\section{Conclusion}

The industrial revolution 4.0 requires many competent human resources to survive in the current era. Humans who have competence today are seen from their abilities. Of course, there are various kinds of abilities needed, one of which is HOTS. HOTS ability is needed because the thought process is not only limited to understanding but also developing, and HOTS can be instilled through learning provided by the teacher. Therefore, the teacher has a vital role in developing HOTS, and so that teacher learning can be applied according to HOTS, the teacher needs to be appropriately trained.

However, Indonesia is currently experiencing a pandemic corona (COVID-19), making it a bit difficult for teachers to conduct face-to-face training. Thus, it is necessary to do it online based on LMS. With the design of structured and structured material, it is expected that teacher competence in providing learning can improve students' HOTS. As for this LMS, the need to involve several parties. Some experts, such as lecturers, experts, experts, and parents, to the government. Collaboration with some of these parties will help teachers understand HOTS better and apply HOTS according to the experience gained from the training process to the insights provided by experts.

\section{References}

[1] M. A. N. Ghiffar, E. Nurisma, C. Kurniasih, and C. P. Bhakti, "Model Pembelajaran Berbasis Blended Learning dalam Meningkatkan Critical Thinking Skills untuk Menghadapi Era Revolusi Industri 4.0," Pros. Semin. Nas. Pendidik., vol. 1, no. 1, pp. 85-94, 2018, doi: 10.1093/0199259259.001.0001.

[2] B. S. Aji, M. A. N. Ghiffari, and C. Kurniasih, "Strategi Layanan Dasar Berbasis Local Wisdom untuk meningkatkan Kemampuan Critical Thinking Siswa di Era Revolusi 4.0,” Pros. Semin. Nas. FKIP, pp. 34-43, 2018.

[3] Y. M. Heong, W. B. Othman, J. B. M. Yunos, T. T. Kiong, R. Bin Hassan, and M. M. B. Mohamad, "The Level of Marzano Higher Order Thinking Skills among Technical Education Students," Int. J. Soc. Sci. Humanit., vol. 1, no. 2, pp. 121-125, 2011, [Online]. Available: http://www.ijssh.org/papers/20-H009.pdf.

[4] C. Anwar, "The Effectiveness of Problem Based Learning Integrated With Islamic Values Based on ICT on Higher Order Thinking Skill and Students' Character," AlTa lim J., vol. 23, no. 3, p. 224, 2017, doi: 10.15548/jt.v23i3.244.

[5] S. Narayanan and M. Adithan, "Analysis Of Question Papers In Engineering Courses With Respect To Hots (Higher Order Thinking Skills)," Am. J. Eng. Educ., vol. 6, no. 1, pp. 1-10, 2015, doi: 10.19030/ajee.v6i1.9247.

[6] A. Saregar, S. Latifah, and M. Sari, "The Effectiveness of Model Learning Cups: Impact on the Higher Order Thinking Skill Students at Madrasah Aliyah Mathla'ul Anwar Gisting Lampung," J. Ilm. Pendidik. Fis. Al-BiRuNi, vol. 5, no. 2, pp. 235- 
$246,2016$.

[7] A. I. Rohmatillah and B. Sujatmiko, "Implementasi Pembelajaran Menggunakan Pendekatan Scientific untuk Meningkatkan Hasil Belajar Siswa dalam Mata Pelajaran Sistem Komputer Di SMK Negeri 2 Surabaya," It-Edu, vol. 2, no. 2, 2017.

[8] S. Hartini, C. Putra Bhakti, D. Hartanto, and M. Alfarizqi Nizamuddin Ghiffari, "Teacher Pedagogic Competency Development Model: A Literature Review," vol. 267, no. Aecon, pp. 211-215, 2018, doi: 10.2991/aecon-18.2018.40.

[9] M. Nursalim, Pengembangan Profesi Bimbingan \& Konseling. Jakarta: Erlangga, 2015.

[10] H. Hikmatiar, D. Sulisworo, and M. E. Wahyuni, "Pemanfaatan Learning Manegement System Berbasis Google Classroom Dalam Pembelajaran," J. Pendidik. Fis., vol. 8, no. 1, pp. 78-86, 2020, doi: 10.26618/jpf.v8i1.3019.

[11] T. Widodo and S. Kadarwati, "Higher Order Thinking Berbasis Pemecahan Masalah untuk Meningkatkan Hasil Belajar Berorientasi Pembentukan Karakter Siswa," Cakrawala Pendidik., vol. 32, no. 1, pp. 161-171, 2013.

[12] F. Kawuwung, "Profil Guru, Pemahaman Kooperatif NHT, dan Kemampuan Berpikir Tingkat Tinggi di SMP Kabupaten Minahasa Utara," el- Hayah, vol. 1, no. 4, 2012.

[13] J. DeMonte, "High-Quality Professional Development for Teachers," Support. Teach. Train. To Improv. Student Learn., no. July, p. 12, 2013, [Online]. Available: papers3://publication/uuid/3692893C-3659-465F-A54C-CC76945E72CC.

[14] A. Mahmudi, "Mengembangkan Kompetensi Guru Melalui Lesson Study," in Forum Kependidikan, 2009, vol. 28, pp. 84-89.

[15] E. R. Sari, "Teacher Professional Development in an Online learning community: A case study of teacher professional development in Indonesia," 2012.

[16] J. Smit, H. a. a. Eerde, Van, and A. Bakker, "A Conceptualisation of Whole-Class Scaffolding," Br. Educ. Res. J., vol. 39, pp. 817-834, 2013.

[17] D. Davis, G. Chen, C. Hauff, and G. J. Houben, "Activating learning at scale: A review of innovations in online learning strategies," Comput. Educ., vol. 125, pp. 327-344, 2018, doi: 10.1016/j.compedu.2018.05.019.

[18] I. Lestari, "Evaluasi Fungsionalitas Learning Management System Berdasarkan ISO/IEC 9126-2,” J. Sains dan Teknol. Ind., vol. 13, no. 1, pp. 123-129, 2016.

[19] Sugiyono, Metode Penelitian Pendidikan: Pendekatan Kuantitatif, Kualitatif dan $R \& D$. Bandung: Alfabeta, 2011.

[20] J. W. You, "Identifying significant indicators using LMS data to predict course achievement in online learning," Internet High. Educ., vol. 29, pp. 23-30, 2016, doi: 10.1016/j.iheduc.2015.11.003. 